\title{
Interdisciplinary Interpretation of the Bible Text
}

\author{
Ying $\operatorname{Han}^{1}$ \\ ${ }^{1}$ School of Foreign Languages, Zhejiang Gongshang University, Hangzhou, 310018, Zhejiang, China \\ Correspondence: Ying Han, School of Foreign Languages, Zhejiang Gongshang University, Hangzhou, 310018, \\ Zhejiang, China. E-mail: hanyinglucy@163.com
}

Received: December 11, 2014 Accepted: January 6, 2015 Online Published: January 27, 2015

doi:10.5539/ijel.v5n1p170 URL: http://dx.doi.org/10.5539/ijel.v5n1p170

This paper is the achievement of the project "Interdisciplinary Interpretation of the Bible Text" (Y201432289) by the Education Department of Zhejiang Province in 2014.

\begin{abstract}
Literature and critical and creative thinking complement each other. The Bible's classics status has been demonstrated and approved by many Western and domestic scholars, accordingly literary criticism of the Bible examined extensively and from different angles. This paper makes an interdisciplinary interpretation of the Bible text from the perspective of literature, history, philosophy and so on. It suggests offering course of literary criticism of the Bible and cultivating critical and creative thinking.
\end{abstract}

Keywords: the Bible, text, interdisciplinary, literary criticism; interpretation, critical and creative thinking

\section{The Status of the Bible}

The Bible is one of the most influencing books in the history of human civilization. In the field of interdisciplinary studies of contemporary culture, the literary study of the Bible shows strong academic vitality to a variety of extremely divergent readings. The Bible is a complete fusion of art of literature, theology, ethics, and historical speculation; if we want to thoroughly know the latter (theology), we must fully grasp the former (literature). The Bible closely relates religious value and literary works value together, the two values being inseparable. In some scholars' eyes, for example Alter, the Bible is a unity of theology, history and literature. In fact, its theological ideas and historical content must be expressed with the help of the language means or literary techniques. Religious view of the Bible is conveyed through the most delicate ways of prose fictions to add its depth (Robert, 1997). This paper makes an interdisciplinary interpretation of the Bible text from the perspective of literature, history, philosophy and so on. It suggests offering course of literary criticism of the Bible and cultivating critical and creative thinking.

\section{Literature Review of Literary Criticism of the Bible}

The research of the Bible in the western countries has a long history. The literary study of the Bible in the academic field, especially in Western countries, is in a very prominent position. Especially in the 20th century called the "critical theoretical century", the researchers got out of the narrow vision of the literature of the Bible, using a variety of critical theories to launch an overall research to the Bible as the literature in a full swing. The works of a group of well-known scholars, such as E. Auerbach, N. Frye, R. Alter, and M. Sternberg, represent the latest achievements in the literature of the Bible during the latter half of the 20th century, especially Alter's The Art of Biblical Narrative, Sternberg's The Poetics of Biblical Narrative: Ideological Literature and the Drama of Reading are recognized as the narrative critical models of the Bible (Alter, 1981; Sternberg, 1987).

However, in China, after the Third Plenary Session, with the ideological liberation movement and the continuous deepening of reform and opening up, literary research of the Bible began to recover gradually, achieving impressive fruits and becoming one of the world's literature focuses that cannot be ignored. Mainland Chinese academics to study the Bible were left behind the Western ones nearly half a century. After 20 years of the reform and opening up (1979-1999), the scholars conducted a whole comb of the literary studies of the Bible in China (Liang, 1999). Domestic research of the Bible in the eighties and nineties mostly stay in the general review or translated level and there are few high-quality research monographs. Until the late 1990s, this situation began to change. 
The author made a statistical analysis of a small-scale of China's Bible literary studies in 2000-2013. Entering with "the text of the Bible" in Chinese journals' database, the results of the accurate search show that 2000-2003 owns 314 pieces; 2004-2007 owns 623 pieces; 2008-2013, 1280 pieces. In terms of the size and quantity, it was very impressive, showing an increasing trend year by year, and the Bible in the world of literature in this field conforms to the proportion in the world; in terms of quality, either the discussion on the Bible in content, ideas, form of skills, style, etc., or the relationship of the Bible with both Western literature and Chinese one, it is encouraging achieving considerably. Scholars have begun to study the Bible from the perspective of ideology. Professor Liu Yiqing's On Influence of the Bible.Old Testament on Ideology, Culture and Politics in Western Countries is a good example (2002). Some scholars made a research of the Bible from the perspective of translation, such as Ren Dongsheng's Thick Translation: Literary Tendency Demonstrated in the Translation of the Bible by Wang Hanchuan. He believes that the Bible in the source language text has a profound cultural implication. The translator only adds a variety of comments or commentary to explain the source language text in a rich linguistic and cultural context (2013). In Minutes of Roundtable Meeting on Contemporary Significance of the Research of the Bible, the Chinese scholars had divergent views of the ancient heritage on how to understand the Bible's complicated connotation, and how to understand the significance of the Bible on contemporary culture construction (2009). Liu Yiqing's Philosophical Reflection on literary interpretation of the Bible, based on social and political realities in foreign countries, analyzes dialectical worldview, metaphysics, and language philosophy, thus demonstrating significance of the Bible beyond the scope of religion (2010). Gong Weiying and Zhao Jianyu suggested the Bible as an education program (Gong, 2007; Zhao, 2012).

\section{Interdisciplinary Interpretation of the Bible Text}

\subsection{Interdisciplinary Flavor of the Bible Text}

The Bible is a great creation, a record of the history of the ancient Hebrews, having become the material treasure in the western literature works. The writers either directly used these stories as their creation materials, or put the implied meanings of these myths into his works to enrich the plot and the character disposition. The Christian culture reflected in the Bible with its vivid and profound forms is reflected in many literary works, from the word, conversation, style, and allusion to theme. Both English and American literature was influenced by it, forming a unique Christian culture and being permeated with a speculative atmosphere of religion ethics, history, literature and philosophy.

\subsubsection{Words}

The words in the Bible are accurate and powerful. Montgomery once wrote in his book History and Christianity, saying "If anyone doubts the content of New Testament from any book, which means he/she downgrades the value of all the classical literature. The reason is that no book in history is more tested than New Testament."(1986) As is known to all, Old Testament is written in Hebrew. It is Jewish people who offered a half Bible. Moreover, Jewish people's efforts in preserving the materials are unprecedented all the time. The special Jewish word system can calculate every letter, syllable, word and paragraph. There is one kind of people in their social culture, whose unique responsibility is to preserve and transmit those Bible materials, and make them errorless and integrated. Those people are scholars, lawyers and the Massoretes. Just imagine, who is willing to calculate the letters, syllables and words from the works of Plato and Aristotle?

\subsubsection{Conversation}

The narrator of the Bible pays much attention to the characters' conversation. When he mentions some phrases or sentences, he doesn't explain the whole meaning directly, and what he does is to show the meaning by reusing the phrases and sentences through one or many characters' conversation. In general, if there is something important, the author will transit the context from narration to conversation to hint his assessment of that importance. For instance, the author just uses fast-paced narration to describe David's rape towards Bathsheba, and uses conversation to show his murder towards Uirah, with the length much longer than the former. It indicates that, in the author's opinion, compared with rape, murder is his main crime.

\subsubsection{Style}

The style of the Bible is implied, brief and repetitive. This kind of writing method requires readers to fill up the content according to the hints to get the whole meaning of the story or get a deeper comprehension. For instance, the story of Abraham giving Isaac to God is quite short, and there is even no description about the characters and scenery. How do Abraham and Isaac look like? How is their personality and temper? What are the names of the two servants? Are they loyal to Abraham and Isaac? There is no word about those. And there are only two explanations, and both are used to describe Isaac. When God ordered Abraham to offer Isaac as an oblation, he 
said, "Take now thy son, thine only son Isaac, whom thou lovest, and get thee into the land of Moriah; and offer him there for aburnt offering....Gen. 22:2" When God stopped Abraham from killing Isaac to assure his loyalty, he said Isaac was Abraham's only son again - for now I know that thou fearest God, seeing thou hast not withheld thy son, thine only son from me....Gen.22:12. In this brief narration, why are these two descriptions used for Isaac? Compared with the nondescription of other characters, is it out of tune? How to view the details and simplicity of the narration in the Bible?

\subsection{Interdisciplinary Interpretation of the Bible Text}

The Bible is in narration. Superficially it is just plots, but in its structure, it contains historical, cultural and philosophical elements. It requires careful analysis to get the reasonable comprehension and answer. The Bible provides many perspectives to let either readers or teachers and students make analysis, synthesization and estimation freely, critically and creatively.

\subsubsection{Art Poetics-Literary Perspective of the Bible Text}

Poetic theory is the writing theory of the Bible. The text of the Bible should not be simply treated as literary stories, but should be regarded as literary entirety. Its literary theme contains the beginning and end of the human history, for instance, the creation, paradise, temptation, punishment, repentance, obstinate, redemption, etc. To sum up, it is about love and redemption. It will be of great advantage to understand the themes of western literary works if readers are sure about these themes of the Bible.

Moreover, the Bible has all of the literary technics, features and genres that the literature should have. Thus in the case of teaching, teachers should lead students to have a macroscopical grasp of the Bible's genres. For instance, the Bible-Old Testament includes the myth, tale, history, short story and philosophical story; New Testament has gospel, allegory and epistolary style. And other people think the Bible's genres mainly include narration and poem, and implied drama; New Testament also contains literary features, especially the gospel, apostle letter and apocalyptic literature.

The aim of teaching the writing theory, literary theme and main genres is to lead students to have a basic macroscopical grasp and guide them to do the interdisciplinary literary criticism. In this way, students won't feel puzzled or confused when they read the Bible. With teachers' guidance, students can have a basic judgement and choice to read the different chapters and texts, based on their personal interests.

\subsubsection{Profound Christian Literature-Religious and Historical Perspective of the Bible Text}

Christianity has a profound and extensive influence on the western civilization. The core of the western civilization is the Christianity literature; western universal value is the Christianity value; and the whole western history is a religious history. It is undeniable that the Bile plays an important role in understanding the Christianity. The Bible is the words of the Gods, the religious classics of the Christianity. Its content is extensive and profound, and it covers all the truths of the Christianity. Of all ages, a lot of scholars, ideologists, historiographer, philosophers and litterateurs spent their whole lives in reading, analyzing, proving and falsifying the Bible, but no one dares to say that they totally understand the Bible. The only reason is that the Bible is the words of the Gods. As the creator, the God's thought is beyond human beings', and the God's wisdom is also beyond human beings'. Human's rationality can never reach the divinity, just as the most intelligent robot that humans invent, can also never understand humans' mind.

The Bible teaches us to know the Jewish nation, the origin of Christianity, the early church, gospel and other related history. But we must be clear that the Bible is not a history book being read as a historical or archaeological one, otherwise it is inevitable to be in absurd criticism and negation of the Bible. The only way is to conjunct the Bible with other historical data, exploring the Christian sequence of events. We also must be clear that missionaries to China will introduce China being the oriental ancient civilization to the west through the description of Chinese culture, forming their own viewpoint of Chinese culture. Views of missionaries on Chinese culture were greatly influenced by themselves, their organization, their nationality, their activities and other factors. As Chinese, we should have a critical thinking of the description by the missionaries of Chinese history and culture, being objective and fair to treat our own country's history.

\subsubsection{Wisdom Literature-Philosophical Perspective of the Bible Text}

The ancient Christianity, the classical scriptures and wise philosophy hand down from the ancient time to nowadays. They have been influencing a lot of generations, and we all expect that they can have new meanings through more imaginative and creative reading. Subsequently in teaching, we should enlarge Bible literature to the subject system of West Asian civilization and classics. Hebrew and Greece civilization are the fountainhead of the western civilization. Hebrew civilization's importance is self-evident, so it is of great importance to spread 
the ancient Hebrew civilization, the Bible included, in college education. Professor Archie Chi-chung LEE sets up Bible's wisdom literature in general education, and this can help students study the detailed Bible text and also put it into college education. The Bible-Wisdom Book includes Job, Poem, Proverb, Ecclesiastes and Song of Solomon. They focus on the ways of survival in the society, and they are a summary of human's living experience, a spread of the experience from the last generations to the next generations. What wisdom literature builds is a practical rational tradition, and it represents another field, apart from law and prophet. Therefore, wisdom literature is compared to thorn (push people to make progress) and steady nails (don't be wavering). Nowadays, wisdom literature is vital. Firstly, wisdom literature advocates open thinking, which is the base of the creativity. Without independent dignity and thought, it is unimaginable to a full-scale personality. However, openness and criticalness, provided by wisdom literature, are very important contents. Secondly, wisdom literature is the beginning of all wisdoms. Among them, openness coexists with criticism, and at the same time, being devotional and respectful to lives and creatures.

\subsubsection{Classical Language-Linguistic Perspective of the Bible Text}

The idioms from the Bible are frequently used in English. The Bible can broaden our horizon, enrich our knowledge and make us have a better understanding of English. Reading the Bible with great concentration can regulate our words and deeds and enrich our knowledge. Nowadays, China contacts with the foreign countries more and more frequently. Reading the Bible has a great effect on understanding the Euramerican customs, accelerating the cultural and commercial exchange, communicating with the western people and understanding the British and American literary works. The Bible, with a distinct rhythm and poetry melody, enriches the expression function of English. It nourishes the English learners generation by generation, like the fresh and sweet spring water. For instance, "Lord, who shall abide in thy tabernacle? Who shall dwell in thy holy hill?" Regarding these sentences, the quantity of the words is similar, the syllable is the same, and the words "abide-dwell", "tabernacle-holy hill" are corresponding. Apart from this, we also can teach students how to translate the Bible.

\subsubsection{Critical and Creative Thinking-Educational Perspective of the Bible Text}

Literature teaching should provide students with the opportunity to be in meditation, imagination, at the same time introducing as soon as possible literary works with rich content to classroom teaching, combining literature, thought and language together. Study and Research on the Bible text can enhance critical and creative thinking (Rubovits, 1997). Since the historical and religious connotation of the Bible must be demonstrated through its literature shell, studying its shell, exploring its narrative skills, has become the inevitable academic mission. In China, we certainly will more deeply and better grasp international advanced methods and skills to interpret literature, broaden our horizon, innovating our thinking, and even changing thinking mode to enhance the ability and cultivate more talents to study foreign literary works if we set up course of literary criticism of the Bible in literary research fields, providing literary and cultural interpretation of the Bible beyond the scope of religion, using a variety of literary theory, literary criticism to train students. Wen Qiufang proposes cultivating students' critical and creative thinking ability from the perspective of curriculum setting (2012).

\section{The Enlightenment of Interdisciplinary Interpretation of the Bible Text on Course of Literature}

It is imperative to set up course of literary criticism of the Bible. This course will neither value the religious theology connotation of the Bible, nor consciously or unconsciously ignore its function being historical document data. It will only pay attention to its literary property, lead the students into the palace of the Bible literature, and provide an atmosphere of appreciation, criticism and reflection for students. In the course students will be trained interdisciplinarily.

From the perspective of cultivating the critical thinking skills, teachers cannot just introduce the literary history knowledge and appreciation. They should help the students to find the problems, and analyze the aesthetic effect, implication and cultural connotation based on cultivating the students' literary connoisseurship, which poses a challenge and makes it demanding for teachers to teach and test students in course of literature (Zha, 2013).

\subsection{Teachers Should Cultivate Their Inner Depth in Literature}

Teachers play a key role in cultivating students' critical thinking skills, so it is necessary to improve their ability. As for the workers of humanistic and social science, the more and more complicated society requires us to have a perfect knowledge hierarchy, change the ideas initiatively and enhance the consciousness of innovation. Besides, we should come up with new thoughts, methods, view and understanding; we should clarify the problems from many perspectives; we should combine the literary aesthetics, appreciation and analysis during the process of literature teaching. Thus, we can do better in booming the humanities and social sciences, building 
an innovation-originated nation, making a harmonious society and building a well-off society in an all-around way.

\subsection{Aesthetics and Thinking Ought to Be Tested in Course of Literature}

It is not enough to only test memorized common senses of literary history by students, because it cannot test students' text analysis ability, and cannot test their aesthetic and appreciation ability, neither. Literature test should match the humanistic care and thought expansion. And social service is a good reflection of them. In the Bible, there are many chapters that describe how to take part in the social service. In course of literary criticism of the Bible, teachers should observe whether the students really take part in the social service to make a contribution to building a harmonious society.

\section{References}

Alter, R. (1981). The Art of Biblical Narrative. Perseus Books Group: Basic Books.

Gong, W. Y. (2007). Biblical Cultural Knowledge and English Teaching. Shandong Foreign Language Teaching Journal, (2), 41-45.

Liang, G. (1999). The 20 Years' Research of the Bible in China (1979-1999). Journal of Jing Zhou Teachers' College, (6), 61-67.

Liang, G. Minutes of Roundtable Meeting on Contemporary Significance of the Research of the Bible. Journal of Henan University (Social Sciences Edition), (3), 84-87.

Liu, Y. Q. (2002). Influence of the Bible-Old Testament on Ideology, Culture and Politics in Western Countries. English and American Literary Studies, (00), 1-15.

Liu, Y. Q. (2010). Philosophical Reflection on Literary Interpretation of the Bible. Literature and Culture Studies, (1), 120-127.

Montgomery, J. W. (1986). History and Christianity. Bethany House Publishers.

Ren, D. S. (2013). Thick Translation: Literary Tendency Demonstrated in the Translation of the Bible by Wang Hanchuan. Journal of Karamay, (1), 73-79.

Robert, R. A Critical and Creative Thinking Bible Curriculum. Critical and Creative Thinking Capstones Collection. Retrieved from http://scholarworks.umb.edu/cct_capstone/265, 1997

Sternberg, M. (1987). The Poetics of Biblical Narrative: Ideological Literature and the Drama of Reading. Bloomington: Indiana Univ. Press.

Wen, Q. F. (2012). Study on the Status of Critical Thinking Ability of English Majors in China. Beijing: Foreign Language Teaching and Research Press.

Zha, M. J. (2013). Minutes of Roundtable Meeting on Assessment and Enhancing Critical Thinking. Foreign Languages in China, (1), 4-9.

Zhao, J. Y. (2012). The Introduction of Literary Criticism of the Bible to Teaching for English Majors. Journal of Chongqing University of Science and Technology (Social Sciences Edition), (6), 188-190.

\section{Copyrights}

Copyright for this article is retained by the author(s), with first publication rights granted to the journal.

This is an open-access article distributed under the terms and conditions of the Creative Commons Attribution license (http://creativecommons.org/licenses/by/3.0/). 